\title{
The Plant in the Mythology
}

\section{Abstract}

In this article we discuss the importance of plants for the people of the Baltic region. We accomplish this by analysing plant name appearance in religious and mythological texts, tales of various genres, proverbs and sayings, beliefs and lots. Human soul's journey to a plant. A soul living in a tree symbolically depicts a newborn. Tree conveys the symbolic meaning of soul worship of trees, related to the cult of ancestors. The symbol of the soul, as a transforming in the tree, conveys the worship of trees, related to the ancestral with cults, for example, a girl transforms your self into the tree since should into hide oneself from the loveless boy or souls after death transforms into the tree. A girl unwilling to marry a widower turns herself into a stone, lime or rue and the widower is unable to take her. A soul living in a tree is only a temporary embodiment before moving to a new existence. A soul of a dying tree (cut down or rotten) becomes the soul of a newborn. Fir and lime symbolise a girl, boughs of a fir - girl's youth. In songs about marriage and polyphonic songs a pine represents manly strength and manliness. For example, apple - fertility factors in the complicate of the children. Apple picking symbolizes the love seeking and receiving. Apple eating - fertility follow - the life birth. Apple after world the future life of human soul.

Myths use plants as symbols of life and of the healing power of nature. Some plants yield poisons and some die in winter, plants can also represent death and decay. The study about plants in mythology may give insight into historical and recent use of plants in the religion.the use of plants in the domains of food, medicine and religion. We examine the common features of plants and deities, the sameness or similarity of plant names, variety in their application, plant use for fabula construction. Similarities between mythological and natural objects allows us to describe the world outlook and emotional attitude of the Balts.

Review Article
Volume 9 Issue 4 - 2017
Daiva Šeškauskaitė*
UAB Kruenta, Lithuania
*Corresponding author: Daiva Šeškauskaitè, UAB Kruenta,
Lithuania, Tel: +370 699 45718;
Email: daiva.seskauskaite@gmail.com

Received: August 17, 2017 | Published: November 24, 2017

\section{Background}

Plants played an important role in the mythology of Baltic tribes. The plants are mentioned in the sources of religion and mythology, mythological sagas, fairytales, proverbs, believes and magical rituals. In the written sources the worshiping of natural objects as well as phenomenons (sky-lights, earth, fire, water, thunder, plants, animals and even rocks) are often mentioned. The worshipings of natural objects and phenomenons is a characteristic feature to most of the older religions. It's actually conected to the religion itself and the mythology [1]. It's a tradition of the Indo-Europeans. We examine the common features of plants and deities, the sameness or similarity of plant names, variety in their application, and plant use for fabula construction. Similarities between mythological and natural objects allow us to describe the world outlook and emotional attitude of the Balts.

The object of research - the plants and their relations with the gods and their use in the mythology. The aim of this study is to assess the role of plant in Lithuanian (Baltic) in the mythology and religion. Sample Study Questions set for the following tasks:

a. Ascertain and determine what plants are dominant in the mythology;

b. Assess and describe the concept of plant in the mythology;

c. Examine the links between the plant and the gods.

\section{Methods}

Plant names in historic annals, chronicles, religion and folklore have been evaluated. Semasiological aspect have been considered. Therefore, species named with names related to each other have been selected. Other methods: scientific literature, logical analysis, tables.

\section{Results}

Plants (trees, forests) have many functions in mythology. They are worshiped as sacred. It is prayed to the deities dwelling in them. Plants serve as mediums between deities and their servants (kriviai ). Trees are like souls. Souls in trees are respected. A soul of a tree becomes a soul of a newborn, after the tree is cut down or roots down. Human soul temporary inhabits or hides in a plant. Herbs are used as a protection against the devil or the thundergod. Plant names are changing together with religious beliefs. This is how pagan names were changed by Christian ones.

The historical sources (the 1249 peace treaty between the Crossaders and the Prussians, the chronicles of Germans, Polish and others, the descriptions of the world, different writers, such as Dlugosz, Simon Grunau, Lukas David and others) mention the worshiping of the sacred trees and forests that is connected to the cults of the ancestors. In his work"Apie žemaičių, kitų sarmatu bei netikru krikščioniu dievus", wich is based on the story of Laskauskas, Jonas Lasickis writes about žemaičiai, who believed 
that their gods live in the forests. One man started to peel of the bark of the tree, saying: If you took my geese and cocks than I'll take your robes. This man believed that the gods actually live under the tree bark, therefore he's harming them this way. The Letts called the oak the god of men and the linden - the godess of women. At first only some forests were worshiped. They might have been conencted to the necrocult or were the old burial grounds. Later these places were desacralised, because people started to diminish the forests, leaving only some of them sacred, in other places continued to worship only some trees. In the 16041618 report of the Jesuits in Riga mentions the Latvians bringing the sacrifices to the treegods - oak and linden. They bring two eggs for the oak, butter, milk, cheese and fats for the linden to ensure the safety and health of their children [2].

The worshipping of trees, in relation to the cult of ancestors, is mentioned in historical sources (1249 peace treaty between the Order and Prussians, Papal bulls, chronicles of Poles and Germans, accounts of the world, Dlugosz, Simon Grunau, Lukas David and others). Latvians regarded oak as the god of men, and lime - the goddess of women. Romove (Romaynis, Romayn, Romehnen) - legendary Prussia sacred oak grove - Romove- is mentioned in $1304 \mathrm{~m}$. by Simon Grunau In "Chrinicle of Prussia" he writes about Rikojota (Rickoyott), were everlasting oak was grawing (war stetis grün, Winter und Sommer). An oak in a Romovè is identified as a place where gods show themselves and a sanctuary in the open air. An oak was more sacred than all the other trees and it was an abode of gods. It served as an altar, with three idols of Patolas, Perkūnas and Patrimpas standing in it. Three names of Prussian gods are Patolas, Perkūnas and Patrimas. Why do they all start with a „P"? Probably in relation to necrocult, whole forests on ancient Lithuanian burial grounds where worshipped at first. Later, during the desacralization of the forest, souls of anscestors where evicted from the trees by diminishing the forests down to separate sacred groves or even a few trees (BRMŠ).

\section{Tree Gods. Gods that Protect and Grow Plants}

\section{The plant gods worshiped by the Balts stand out the most}

a. Beržulis: The birch god, is mentioned by Lasickis [3] and Pretorius calls him the god of birches leafage and the birch sap [2].

b. Bibčiu Bobelis: The garden god,mentioned in the works of Brodovski. This god is compared with Priapas and this shows the significance of the god, who later became not only the god of the garden, but also the god of fruitfullness, bess and everything else that is in the garden [2].

c. Blindé: A woman, who was very fertil and could give birth from her hand and legs. The earth was jelous of her fertility, so she turned Blinde into a tree. She is mentioned by Narbutas, Jucevičius, Kraševskis [2].

d. Diemedis: Lithuanian diemedis and Latvian dievakoks represent the most frequent vernacular names of southern wood Artemisia abrotanum. These plant names appear quite frequently in Lithuanian and more seldom in Latvian folklore, especially in folk songs and speeches given during traditional wedding ceremonies. Here, southern wood goes as symbol of the groom or any young man. Quite often, the properties mentioned point to a tree, not a shrub. For example, the tree diemedis is suitable for a falcon or peacock to take a seat. Literally both diemedis and dievakoks mean God's tree. The plant, however, is a small perennial shrub. Lithuanian and Latvian names of southern wood appear as early as the 17 th century in the earliest dictionaries. An overview of vernacular names of the plant in many European languages shows a picture as follows. While in the South, West and North Europe most names are loans based on Latin abrotanum and remakings of them by means of folk etymology, other names refer to officinal use or smell. However, in the Eastern Europe, namely, in all Slavic and Baltic languages the plant names meaning "God's tree" dominate. Moreover, we can come across such instances in the Romanian and Hungarian languages. Their origin seems to be Old Greek habrotanon 'Artemisia sp.' of unknown origin, which was related to ábrotos 'immortal, divine' in folk etymology. In Slavic environment, the plant, thus being a divine plant, was subsequently identified with the already existing "God's tree" in folk belief and custom. When brought to the Balts, the plant was identified and its name was adopted. Lithuanian dievo medis is a calque of Slavic origin. As the old God's tree is described in folklore, it may be seen as a trace of the world tree concept, which is used as a ritual place during wedding ceremonies. Other views are possible, of course. Some texts show the changes indicated by the real plant onto the view of 'God's tree; for example, diemedžio krūmelis 'God's tree shrub', or the growing part in the bed of flowers [4].

e. Dirvolika: Lithuanian goddess of grain. She was sacrificed boars. They worship the god and Nosoliaus (Nosolum) were associated with land and water belonged to what will be harvested, which is mentioned in Jesuit reports [2].

f. Egle: Origin and use are in the Lithuanian language. Derived from the word egle which is of the meaning ,spruce, fir tree. The name was borne in Lithuanian mythology by the Queen of Serpents, or the Queen of Grass Snakes, also a noun meaning spruce (Picea) [5].

g. Giraitis: The god of the forest. M. Pretorijus and Brodovski call him the forest god of the Lithuanians, while Ruigys is the forest god of the pagans [2].

h. Ivulis: Iwas/Ywas - (BRMŠ III). Lithuanian ievà and Russian iva (Salix spp.) are usually put together with yew, German Eibe (Taxus baccata) (Friedrich 1970; Katičić 2003). Formally, this view is possible. Semantically the transformation needs more explanation. We may also consider crisscrossing influence between names and concepts of Lithuanian ieva 'bird cherry', juvis 'yew', javoras 'ritually used tree'. Friedrich (1970) says that the underlying commonality of supposed cognates yew, Russin iva, Lithuanian ieva, Hetthite eyan 'evergreen tree used as ritual sign' (probably Taxus baccata) can be found in their ritual use. With regard to the Balts, we have no firm evidence for ritual use of yew. However, in spring rituals and festivals, there is wide use of the so-called verba, related to the Church Palm Sunday but being, of course, of older origin. This item is made of twigs from either willow or juniper; one of them being evergreen, as is the yew, and the other - Salix caprea - being the first to flower [6]. 
i. Javine: Also a godess of the grains, mentioned by Brodovski. Some think that she's a collision of other gods of the grain [2].

j. Jovaras: is the wreath of newly harvested crops is plaited from stalks of rye, or other harvested grains, and is bound by winding straw around a bundle. In most cases, the semantics of jovaras and its various cognates are or may be related to the process of twisting or plaiting. One may suppose that jovaras, in the harvesting song, is not a tree at all but a material object like a straw bundle or a maypole, plaited or decorated with straw and maybe, herbs. This could explain why jovaras grows in the middle of the gate or why it has to be lifted to pass through the gate. The song texts, where jovaras is situated in the gate, at the window, as well as inside the house, seem to support the assumption that what is discussed is indeed an artefact, which may be easily divided into several parts. Its earliest sense a material object, an artefact, and only later does it come to refer to natural species. Artefacts do not bloom. The artefact is used ritually - hence it is called Dievo medelis 'God tree'. The poem-riddle is a cultural pun or sorts, as it plays on the layered meanings of the term jovaras, as both braided objects and living trees, and captures the overlap and ambiguity of its varied meanings. The riddle itself captures the symbolic history of the term and its transformations, which when uncovered, or un-braided, in fact tells the story of past uses in path construction, spring rites, marriages ceremonies, children's games, handicrafts and botanical nomenclature. Such a compound would be in agreement with the above mentioned fact that the jovaras/jievaras is often situated at the gate of the yard and the idea that it could be - in certain situations - also an artefact, e.g., the boom in the gate. If we look at the archaeological evidence about buildings with earthed poles the semantic relation between 'to stick' and 'pole' is obvious [6].

k. Kukalis: lith. kūkalis 'corn-cockle'. Possible semantic derivations include the rise from seed capsules of weeds and relation to Lith. kaukas 'a demon, hobgoblin'. The corn-cockle is shown to be a suitable candidate for a botanical representation of the corn mother, a predecessor of skalsa 'Claviceps purpurea' also 'blessing, abundance' which is strongly related to the kaukas. From this corn demon rose penates kukolis 'hobgoblin', kūkole 'snake'. Traces of worshipping this mythical beeing are found in the archaic polyphonic songs Sutartines and in some Dainos. Similar development of kaukas, kūkalis and Sl. pendants are reported. In connection with the plant kükalis and the possibility that this is the representative Korn is a demon, should be made to the beneficent function of the Kaukus [7].

I. Kupolė: The spirit of springtime vegetation and flowers. Kupolè present plants in flowering and growth from May until end of July, the overall growth of vegetation, growth, flowering peak. The terms of the Kupole can be regarded as the goddess or deity that owns at the time of blooming and growing plants.

m. Krūminé: a godess who gives all grains. About Krumine M. Stryjkowski writed in work "Chronicle of Poland, Lithuania, Samogitia and all Russia", Jan Lasicki in a treatise"About gods of Samogitians, other Sarmatians, and false Christians" (De diis Samagitarum caeterorumque Sarmatarum et falsorum
Christianorum) (Lasickis 1969). People made offerings to her, wanting that their ryes would grow strong and big- eared. G. Beresnevičius think that Krümine should be held a godess of the grain field [2].

n. Kerpyčius: the god of the forest [2].

o. Kirnis: the god of cherrys [2].

p. Laibegelda or Luibegelda: [2].

q. Laukosargis: god of grains and other agricultural plants.

$r$ Lazdona: The godess of the walnut, mentioned by Lasickis [3]. She watches over the nut-trees [2].

s. Medeina, Medeine, Modeina: is the Lithuanian godess. She's mentioned in the annals of Ipatius, the Polish history of Dlugošas, in the book of Laisckis "Apie žemaičių, kitų sarmatu bei netikrus krikščionių dievus" [3]. She is conected with the Žverrine, Žvorūna, who was mentioned in the cronicles of Malala. She was the only godess who reached the very top of the Lithuanian pantheon. Even Lithuanias only king Mindaugas made sacrifices to her. Her name derives from the name of the forest, a tree in Lithuanian (medis, miškas). The god of rabbits is held as an epitet of Medeina or sometimes as a self- dependance god. The name Žvorūna derives from the name of the western star. Acording to the Ž. Diumezilis classification of gods functions Nunadievis and Andajas fulfil the juridical, Perkūnas carry out the military, Teliavelis - the highest magical and economical functions. Medeine, Žvorūne and the rabbit god is tied with the economical function as well. Teliavelis is conected to the domestic animals while Medeina and Žvorūne to the wild ones. Medeina and Žvorūne are conected with the Mother of all gods, mentioned in the works of Tacitus [8].

t. Nosolus: the god of the grain [2].

u. Pagirnis: (Jesuit reports 1605).

v. Pergrubris: the god of grass, leaves and sommer. Prussian god of spring and flora ascribed to Lithuanians as well. First mentioned in "Sūduvių knygelë' as a god who stimulates the grow of the leaves and the grass. Motiejus Strijkovskis mentions him as a herb and vegetable god as well. He grows all sorts of shoots, flowers, grass etc. People asked Pergrubris to watch over the young seedlings and exterminate the weeds. Jonas Maleckis-Sandeckis in his work "Apie senovès prūsų, livoniečiu ir kitų kaimyninių genčių religiją ir aukojimus" writes about offerings to Pergrubris on St. Georges day. Lasickis and Jonas Maleckis-Sandeckis also add that Pergrubris is a god of spring. M. Pretorijus adds that he was a labour god. Toporovas derive this god from the Lithuanian words grubus, grublas which meen a rough surface [2].

w. Pušaitis: earth god, who live among the elder bushes. Offerings were given to him in the evening, next to the elder bush. He was given bread and bear, so that he would send his subjects (dwarfs - barstukai) to help the farmers. Pušaitis was beeing worshiped twice a year and his minions barstukai were cherished and respected. Jonas Maleckis-Sandeckis writes that Pušaitis was the guardian of the sacred forests. Jonas Bretkūnas in the cronicles of the Prussians writes about sūduviai, who held the elder bush the residance of the gods. 
Table 1: The mythological names in this dictionary are used in botanical nomenclature.

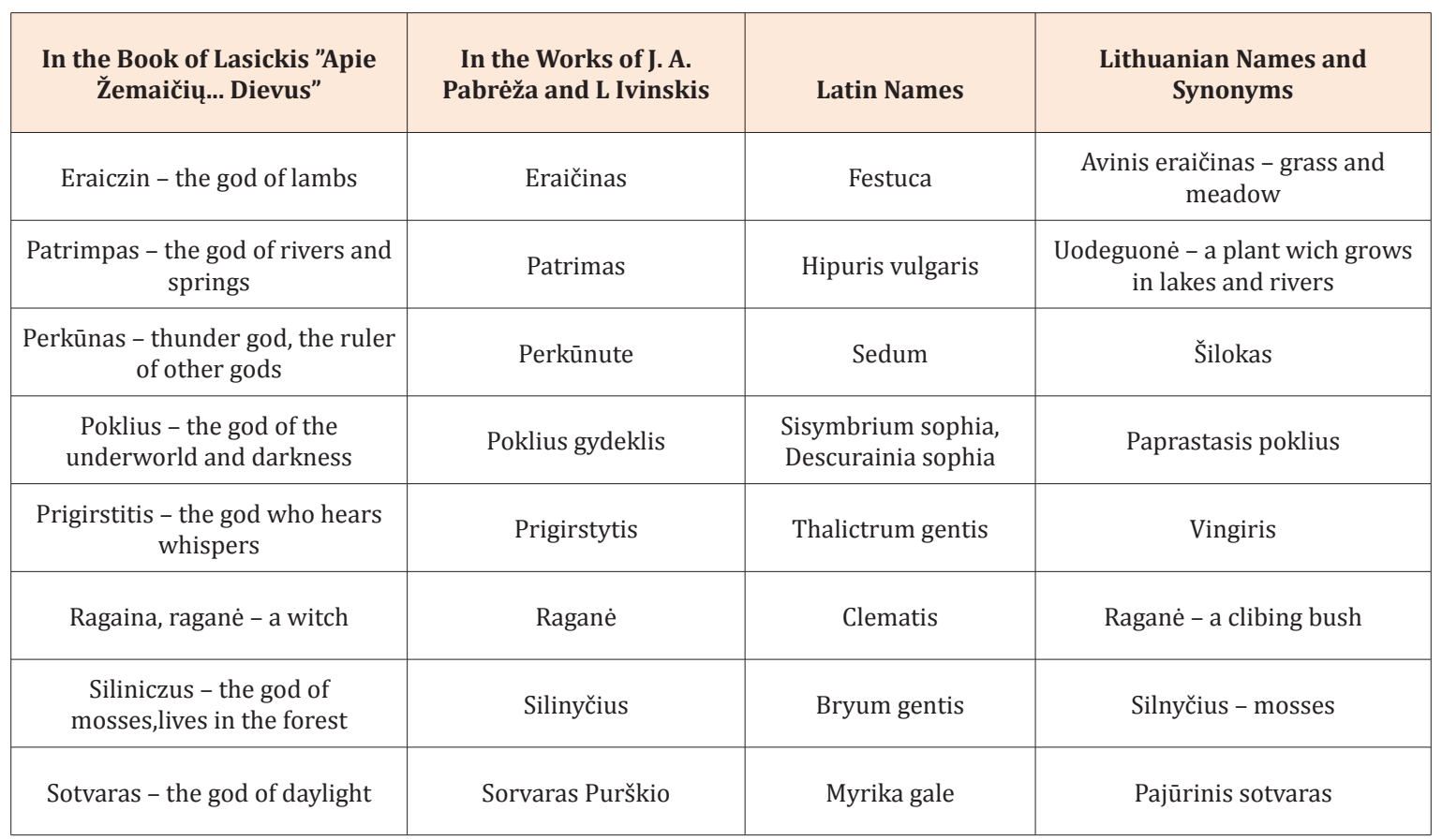

x. Vaižgantas: a god of flax [2,3].

y. Žélius (Zelus): M. Pretorijus call him the god of grass [9].

List of Gods and Goddesses in the lithuanian religion, these religious and historical sources to examine. It requires study. The task of historical discourse is to identify the sources which can most usefully contribute to the identification of accurate accounts of past. Traditionally, christians or istorians have recorded events of the past, either in writing or by passing on an oral tradition, and have attempted to describe the study of written documents and oral accounts. Hierarchy distributed: gods, goddesses, god of euphemism, the spirit of the heroes, guardians, religious artifacts, or ritual ceremonies.

People believed that the spirits of those who passed away live in the trees, so it was forbiden to cut them down. Places were the trees were growing or were there were stumps, were not siuted $t$ build a house. Old people believed that devils live under the stamps. If a house was to build afterall the stamp should be removed at all costs. There was a saying that the sound trees make is actually the sound of the dead. The afterdead passing to a tree was understood as a temporary adobe, before the spirit passes on to the land of the forefathers. The Lithuanians in Žemaitkiemis thought that after a year the spirits of the dead passes to those that are born. In the report about Žemaitkiemis, in the Jokūbas Lavinskis letter to Jonas Paulius Kampanas (1583) the old pagan rituals are written down. It's said that babys who die before christening are brought and layed in a laiden, because they think the groug is sacred. In this concrete case the deceased is layed in a tree -this shows the old world outlook, a ritual, when one believes in the sacred powers of the tree and spirits futher exitance in a tree as well. When the Balts were still pagan - they beleived that everything around them is sacred, after the christening this view changes. In his works about the religions of the Australian tribes Durkheim says that the spirit of the deceased returns to a tree nanja, where it once again merges with its ancestors spirits. This is the way to summarize the consept of the soul as well as its origins: every newborn has a religious and a mystic rudiment within him, which comes from his forefathers; every birth is an incarnation.

The life in a tree is only a temporary incarnation of the soul, its position before it passes on to another existance. If a tree is cut off or is roten, the soul passes to a newborn. This sort of incarnation shows us just how important the trees actually were.

A firtree or a linden simbolizes a girl, while the branches of a firtree in a mariage ritual simbolizes her youth. A pine simbolizes a man. A girls temporary incarnation to a tree is sometimes necessary, because of social, physical or mythical reasons.

In fairytales a girl, who wishes not to mary a widower turns to a rock, a linden or a rue and the widower can't take her away:

Ajau per kiemeli, klausiau per sieneli -

kalba tèvulis su našliu žodelį.

- Nekalbék, tèvule, su našliu žodelio,

ba su našlaliu sunki buitelè.

Oi aš nuvejjau lygana laukelin

oi, aš pavirtau sieru akmenèliu.

Atajo našlalis su palšais jauteliais,

verté akmenèli - ne mani, mergeli. 
Oi aš nuvejau žaliojon girelèn,

oi aš pavirtau žaliają liepele.

Atajo našlalis su plieno kirveliu,

kirto liepeli - ne mani, mergeli.

Oi aš nuvejau rūtelių darželin,

oi aš pavirtau žaliuju rūtelị.

Atajo našlalis su mažais vaikeliais -

skynè rūteli, ne mani, mergelị.

Našlys atstodamas gailiai apsiverké:

Vai kytra mandra tèvulio dukrelé.

I walked across the yard and I heard -

Talked father and a widower one word.

- My father, do not talk with a widower a word,

Because to live with a widower are difficult.

Oh, I went to the field

Oh, I've turned into a gray stone.

A widower conducted the steers,

Inverted the stone - not me, the girl.

oh, I went to the green forest,

Oh, I've turned into green Linden,

Come a widower with a steel ax,

Crossed the Linden - but not me, the girl.

Oh, I went into the garden of rue,

Oh, I've turned into a green rue,

Come a widower with him children -

Picked the rue - but not me, the girl.

Widower gone out (left me) and cried plaintively:

Oh, clever father's daughter.

When a girl turns to a tree or a rue or even a rock it's said that the widower takes cuts down a tree, picks up a rue or takes a rock instead of the girl. This shows that a man can incarnate in a natural object,but stay alive as well.

\section{The spirit which lives in a tree simbolizes a baby}

In the series of fairytales "Ragana neša berniukq maiše" (AT 327 C, F) the "old people" are advised to cut down a thick tree, make a doll, dress it up and and it'll become a child. Hte spirit from the tree will incarnate into the child. In a fairytale "Apgautas karalius" [10] a queen gives birth to tree children, but her sisters trow them out true the window and write to the king, who is on a batle, that the queen gave birth to a dog, a cat and a treetrunk.

\section{The religious and simbolical meenings of a tree}

In the field of religion the most important trees are the deitys and treir mediators, the adobe of the deitys. The oak (Quercus spp.), linden (Tilia cordata Mill.), elder (Sambucus spp.),birch (Betula spp.),nut-tree (Corylus spp.). They are sacred. Personifined tree -a hero- blinde (Salix caprea L.). In an ancient religion of the Balts not only these trees were significant, but also the trees that are grown together, plumpy and those with many shoots. Even know these kind of trees are special. There are trees that simbolize the masculine and feminine rudiments, good and evil, growth and hierarchy. Oak represents a man, linden - a woman, an appletree (Malus spp.) represents them both. In the oaks group we can find the pine (Pinus spp.), the mountain ashtree (Sorbus spp.), ashtree (Fraxinus spp.), aldertree (Alnus glutinosa, A. incana L.), maple (Acer spp.), snowball-tree (Viburnum spp.). the line of the linden contains a firtree (Picea spp.), cornel (Cornus spp.), cherrytree (Prunus cerasus L.). They manifest them selfs in the folklore.

In the folklore the oak and the pine show the man's strengh, might, his manhood. When we talk about trees in folklore, which take part in hero action, the tree that is most oftenly mentioned is an oak. While on the other hand, when the devil is mentioned, we find alder or others moisture loving trees. The oak in this case means not only the strongest, toughest tree, but also the incarnation of a man. In the Old Prussian Ramove (the grove of the holy oaks) the oak is the legendary adobe of the gods. In fairytales, folksongs, folktales the oak plays a part as a symbol for strength and manhood. If a something happens, it's usually happening near an oak. In a folksong"Po qzžuolèliu" ("Under the oak") a rue and a lilly is growing under the oak, while in reality it's actually imposible. Flowers need more sunlight, than the shade of an oak can provide. Here the oak represents the man while the lilly and the rue represent the girls inosence and the girl it self. In the tale of Adom and Eve it's said that they layed under an oak as well. In the Easter song "Skrido, skrido du pilki karveliai" the pigeons bring some oak acorns while the golden dew falls on them. In the old initiantion ritual girls are lifted in to the oaks by the elder women. Here the oaks simbolize the mans strengh in a sexual act. The words sung by few people become a strong force, which can turn a person into a tree. In the fairytale "Sesuo ir devyniagalvis slibinas" ("The sister and the nineheaded dragon") a sister is hideing from the dragon in an oak. It symbolizes the defloration. The oak symbolizes the rudiment of a man. In Medžiokalnis near Kražiai there was a sacred oak, that was visited by women with all sorts of wishes. They oftenly knealed under the oak, brought offering and other things. Mostly however the oak was visited by childless women, wishing they could have babys and be healthy. After the christening people decided to build crosses there. This sacred oak is visited even now.

An oak can also be an adobe of the gods. In the niches the idols of the most important deitys Patrimpas, Perkūnas and Patulas oftenly stood. Under the oak the everlasting fire always burned. So, the oaks were understood both in the religious and symbolical planes.

In the Prussian cronicles of Grunau speaks of the oak in Rikojota: big, strong, tall, mighty, the adobe of the devil. The 
idols of the gods stood there and that this tree was evergreen in summer and in winter, the leafage of this tree was so thick that no raindrop could get throuh. It is said that in the XVI century the oaks ocupied about $15-20 \%$ of the Lithuanian forests. However, now some researchers insist that this percentage is exagerated. In nowadays the percentage of the oaks is only 1,8 . The best climate and soil for the oaks to grow is in Lithuanian seaside region [11]. The oak in Rikojota was also near the sea.

Sometimes the functions of an oak is taken by the appletree. The nineheaded dragon wants to eat the girl siting in an appletree, the grass-snake which seduced.

Eve lays in an appletree as well. Apple oftenly symbolizes fertility. The picking of the apples symbolize a search and the finding of an object. The eating of an apple symbolize a new life birth. In the underworld an apple symbolizes a human soul.

Herbs and plants are often used as a protection from the devil or the thunder. In the postilla of Wolfenbuttel (1573) the rituals, the worshipings and the traditions that are conected with the old religion, faith, magic are writed down. It is said that the herbs and the plants that are gathered during St. Johns day and the day of the Assumption of Blessed Virgin are oftenly used for fortune tellings or to keep off the devil and other evil spirits (Vèlius 1983: 150).

The plants are oftenly used to heal or to course somebody. For magic rituals people mostly used the whole plant. To heal a human they usualy spoke all sorts of magical words to a plant. A woman named Kotryna, who lives in Tilže healed the blind ones with the tree barks which fell of the birch fences.

The names of the plants are usualy folkish, taken from the literature, the mythology or Christian. In the dictionarys the plants are introduced in a specific order: the main name of the plant, the Lithuanian synonyms for it, its Latin name, its species, family, tribe, its growing places, usage. There are many plants which got treir names from Lithuanian mythology. Jurgis Ambrozijus (Ambraziejus) Pabrèža published his work "Botanika arba Taislius auguminis" in he wrote about all sorts of new plant species found in Lithuania and for the names he oftenly used folk ones, such as the names of the deities. Even if he was a priest he gave Lithuanian deity names to 43 plants, using the book of Lasickis "Apie žemaičių, kitų sarmatų bei netikrus krikščionių dievus" (1969 m.) ("De deis samogitarum, ceterumque Sarmatarum et falsorum Christianorum" $1615 \mathrm{~m}$.) and the material from an article by Ivinskis "Diewajtej Lietuwiu ir Žiamaijcziu pirm Krikscionistes amžiaus" which was published in 1864 in a calendor.

The mythological names in this dictionary are used in botanical nomenclature. When Pabrèža presented the new species, some of them were from Lithuanias region - Žemaitija therefore got names that are connected to this region. That shows the deep patriotism of J. Pabrèža. He worked not only for him self but for his homeland as well [12-20].

The names pagans used were soon changed to the Christian ones. These names were given according to the color, function, the time of vegetation or blooming. For example the spring primrose were called rakteliai (in Lithuanian - pavasarinè raktažolè), but after the christianing it was renamed as St Peter's keys rakteliai. Many other plants also were given new names.

\section{Conclusion}

In mythology plants (trees, forests) carry out all sorts of functions. They are worshiped; one gives offerings to deity living within the tree. The plants are also the mediator between the gods and their subjects.

Spirits of the dead also live within the trees, therefore they are respected. When a tree dies the spirit passes on to a newborn.

a. A human spirit can hide not only among, but also within a plant.

b. Trees, herbs are used to protect from the devil.

c. The patriotism of the priest Jurgis Pabrèža alowed Lithuanian mythology to take root within the plant nomenclature.

d. The names of the plants are beeing changed, because the understanding of our suroundings, our religion changes as well. That why the old pagan names were changed to Christian ones.

\section{References}

1. Vèlius (1996) Baltų religijos ir mitologijos šaltinių pobūdis. In: BRMŠ I: Baltų religijos ir mitologijos šaltiniai, p. 22-49.

2. Beresnevičius Gintaras (2001) A short dictionary of Prussian and Lithuanian gods. Aidai, Vilnius, Lithuania.

3. Lasickis J (1969) Apie žemaičiu kitų sarmatų bei netikrų krikščioniu dievus (De diis Samagitanim caeterorumque Sarmatarum et falsorum Christianorum). K. Korsakas and all. Vaga, Vilnius, Lithuania.

4. Daiva Šeškauskaite, Bernd Gliwa (2010) The Botanical Identity and Cultural Significance of Lithuanian Jovaras: An Ethnobotanical Riddle. Ethnobotany in the new Europe. People, Health and Wild Plant Resources 2010. In: Manuel Pardo-de-Santayana \& Andrea Pieroni (Eds.), Oxford, Berghahn Books, New York, USA, pp. 247263.

5. Beresnevičius Gintaras (2003) "Eglè žalčiu karalienè" ir lietuviu teogoninis mitas: religinè istorinè studija ("Eglè Queen of Serpents" and the Lithuanian Theogenic Myth: a Religious and Historical Analysis). Culture, Philosophy, and Arts Research Institute, Vilnius, Lithuania.

6. Daiva Šeškauskaite, Bernd Gliwa (2010) Kas bendra tarp dievmedis ir dievai? Respectus Philologicus. Humanistyczno - Przyrodniczy $17(22)$.

7. Šeškauskaitė D, Gliwa (2005) Lit. kūkalis - Pflanze, Korndämon und Kobold. Res Balticae 10: 69-111.

8. Matas Pretorijus (2004) Prūsijos įdomybès, arba Prūsijos regykla. Inge Lukšaitė \& Vilija Gerulaitienè (Eds.), Pradai, Vilnius, Lithuania.

9. Basanavičius Jonas (2003) Lietuviškos pasakos. Tautosakos biblioteka. 6 tomas. Vaga.

10. Navasaitis M, Ozolinčius R, Smaliukas D, Balevičienė J (2003) Lietuvos dendroflora. Kaunas, Lutute, Lithuania.

11. Dagys Jonas (1937) Kaip kunigas A. Pabrèža augalų vardyną kūrè. Gamta 2(4): 131-135.

12. Beresnevičius Gintaras (2003) Eglè žalčiu karalienè ir lietuviu teogoninis mitas: religinè istorinè studija ("Eglè Queen of Serpents" and the Lithuanian Theogenic Myth: a Religious and Historical Analysis). Culture, Philosophy, and Arts Research Institute, Vilnius, Lithuania. 
13. BRMŠ (2005) The sources of Baltic religion and mythology. ( $4^{\text {th }}$ edn), The institute of Education and Publishing, Lithuania.

14. Ivinskis L (1864) "Diewajtej Lietuwiu ir Žiamaijcziu pirm Krikscionistes amžiaus".

15. Laurinkienè N (1990) Mito atšvaitai lietuvių kalendorinèse dainose. Vaga, Vilnius, Lithuania.

16. LBŽ (1938) Lietuviškas botanikos žodynas. Formed by the commision of botanical dictionary, led by L. Vailionis. In: J Dagys (Ed.), Kaunas, Lithuania.
17. Pabrèža J A (1900) Botanika arba Taislius Auguminis. JAV.

18. Šeškauskaitė Daiva (2001) Sutartinès-senovès apeiginės giesmes. Dakra, Kaunas, Lithuania.

19. Daiva Šeškauskaitè (2011) Erotika tautosakoje (Love and Erotic in Folklore). Kruenta, Lithuania.

20. Usačiovaitė E (1999) Augimo samprata tradicinejje lietuvių kultūroje. In: Augalų ir gyvūnų simboliai. Gervelè, Vilnius, Lithuania, pp. 38139. 